\title{
PENGARUH KEWAJARAN HARGA DAN CITRA PERUSAHAAN TERHADAP KEPUTUSAN PEMBELIAN ULANG PADA PENUMPANG MASKAPAI CITILINK INDONESIA
}

\author{
Arif Fakhrudin ${ }^{1}$ \\ Manajemen Transportasi, STTKD YOGYAKARTA \\ Yogyakarta, Indonesia \\ ariffakhrudin21@gmail.com
}

\begin{abstract}
This study aims to analyze the influence of price fairness, corporate image on the repurchase decision of the Citilink Indonesia. The samples used in this study is 55 samples with deploy the questionnaire to the user the Citilink Indonesia that meets the criteria. Analysis of data in this study uses the analysis multiple linier regression.

The result inficated that all variabels is positif effect, and have a significant effect. Variabel price fairness have a significant partial effect on the repurchase decision, show by the value of $t_{\text {count }} 3,016$ is greater than $t_{\text {table }} 2,005$ and a significant value of 0,004 is smaller than 0,05 and on variabel corporate image have a significant partial effect on the repurchase decision, show by the value of $t_{\text {count }} 4,094$ is greater than $t_{\text {table }} 2,005$ and a significant value of 0,000 is smaller than 0,05. Variabel price fairness and variabel corporate image have a significant simultaneous effect on the repurchase decision. This is indicated by value of $F_{\text {count }} 15,741$ is greater than $F_{\text {table }} 3,18$ and a significant value of 0,000 is smaller than 0,05 . The influence of price fairness, corporate image on the repurchase decision of the Citilink Indonesia is $37,7 \%$. This is shown by the number $R^{2}$ (R Square) is 0,377 or $37,7 \%$, while the rest $62,3 \%$ influenced by other variables not examined.
\end{abstract}

Keywords: price fairness, corporate image, repurchase decision.

\begin{abstract}
Abstrak
Penelitian ini bertujuan untuk menganalisis pengaruh kewajaran harga, citra perusahaan terhadap keputusan pembelian ulang pada penumpang maskapai Citilink Indonesia di Bandar Udara Halim Perdanakusuma. Sampel yang digunakan dalam penelitian ini yaitu 55 sampel dengan menyebarkan kuesioner kepada penumpang maskapai Citilink Indonesia yang telah memenuhi kriteria. Analisis data dalam penelitian ini menggunakan analisis regresi linier berganda.

Hasil penelitian menunjukan bahwa semua variabel berpengaruh positif. Variabel kewajaran harga mempunyai pengaruh parsial yang signifikan terhadap keputusan pembelian ulang, ditunjukan dengan nilai $t_{\text {hitung }}$ 3,016 lebih besar dari pada $t_{\text {tabel }}$ 2,005 dan nilai Sig. 0,004 lebih kecil dari pada 0,05 dan pada variabel citra perusahaan mempunyai pengaruh parsial yang signifikan terhadap keputusan pembelian ulang, ditunjukan dengan nilai $t_{\text {hitung }} 4,094$ lebih besar dari pada $t_{\text {tabel }} 2,005$ dan nilai Sig. 0,000 lebih kecil dari pada 0,05 . Variabel kewajaran harga dan variabel citra perusahaan mempunyai pengaruh simultan yang signifikan terhadap keputusan pembelian ulang. Hal ini ditunjukan dengan nilai $F_{\text {hitung }} 15,741$ lebih besar dari pada $F_{\text {tabel }}$ 3,18 dan nilai Sig. 0,000 lebih kecil dari pada 0,05. Pengaruh kewajaran harga dan citra perusahaan terhadap keputusan pembelian ulang sebesar $37,7 \%$. Hal ini ditunjukan dengan diperoleh angka $\mathrm{R}^{2}$ ( $R$ Square) sebesar 0,377 atau $37,7 \%$, sedangkan sisanya $62,3 \%$ dipengaruhi oleh variabel lain yang tidak diteliti.
\end{abstract}

Kata kunci: kewajaran harga, citra perusahaan, keputusan pembelian ulang. 
Jurnal Manajemen Bisnis, Vol 10. No.1, Maret 2019, E-ISSN:2622-6308 P-ISSN:2086-8200

Website: http://journal.umy.ac.id/index.php/mb

DOI:10.18196/mb.10168

\section{PENDAHULUAN}

Jasa transportasi penerbangan sudah menjadi pilihan untuk bepergian ke luar kota bahkan ke luar negeri, dikarenakan waktu yang lebih singkat untuk sampai ketempat tujuan, harga yang wajar dan dapat dijangkau oleh masyarakat, serta pelayanan dan fasiltas yang diberikan oleh maskapai penerbangan. Jasa penerbangan sangatlah banyak diminati oleh konsumen apalagi oleh konsumen yang memiliki mobilitas yang tinggi. Hal ini banyak dimanfaatkan oleh berbagai jasa penerbangan untuk memulai bisnis mereka. Barbagai agen Travel banyak yang mengeluarkan berbagai promosi harga penerbangan yang relative murah sehingga banyak diminati oleh konsumen. Hal itu menjadikan persaingan cukup pesat dalam hal kemampuan maskapai untuk memberikan fasilitas terbaik, pelayanan, harga yang ditawarkan dan bagaimana citra perusahaan maskapai dimata konsumen sehingga diminati oleh konsumen untuk pembelian ulang tiket penerbangan yang sama. Salah satu maskapai penerbangan di Indonesia adalah PT Citilink Indonesia Airlines yang beroprasi sebagai Citilink Indonesia (Simanjuntak \& Soesanto, 2018). Citilink Indonesia merupakan maskapai yang paling cepat berkembang di Indonesia sejak tahun 2011, ketika mengambil A320 pertama dan percepatan ekspansi sebagai bagian dari upaya oleh group Garuda untuk bersaing lebih agresif pada segment budget traveler. Citilink Indonesia dibenak konsumen adalah maskapai dengan predikat low cost carrier, atau maskapai dengan biaya yang rendah. Citilink Indonesia mampu memposisikan dirinya sebagai maskapai penerbangan yang menawarkan konsep value for money dengan menawarkan harga tiket yang murah tetapi tetap menjanjikan dalam pelayanannya. Walaupun Citilink Indonesia berusaha untuk memberikan pelayanan yang baik kepada konsumen tetapi kekurangan dari kinerja pelayanan dari maskapai ini tetap ada. Seperti buruknya pelayanan yang dilakukan oleh maskapai penerbangan Citilink Indonesia. Keluhan dari konsumen akan membuat citra perusahaan tersebut menjadi buruk dan mempengaruhi kepuasan dan minat konsumen untuk melakukan pembelian ulang. Keputusan Niat pembelian ulang merupakan salah satu faktor penting bagi perusahaan. Niat pembelian ulang terhadap suatu produk tersebut timbul karena konsumen merasa puas akan produk yang dibeli sebelumnya. Salah satu kunci dalam menciptakan niat pembelian ulang adalah dengan meningkatkan kepuasan pelanggan (Savitri, 2018). Salah satu strategi untuk memenangkan persaingan adalah strategi membangun citra perusahaan. Sebuah keharusan bagi perusahaan untuk mampu membangun citra perusahaan yang baik dimata pelanggan maupun public (Suryonaningsih, 
Jurnal Manajemen Bisnis, Vol 10. No.1, Maret 2019, E-ISSN:2622-6308 P-ISSN:2086-8200

Website: http://journal.umy.ac.id/index.php/mb

DOI:10.18196/mb.10168

Paramita, \& Hasiholan, 2016). Citra perusahaan didefinisikan sebagai kesan tentang suatu merek, sehingga merek itulah yang hanya ada dibentuk konsumen. Konsumen yang telah terbiasa menggunakan merek tertentu yang muncul dalam benak konsumen karena semakin banyak atau seringnya konsumen menggunakan produk atau jasa tersebut (Budiastari, 2018).

Menurut Kotler dan Keller (2007), harga dapat diartikan sebagai jumlah uang (satuan moneter) dan aspek lain (non-moneter) yang mengandung utilitas atau kegunaan tertentu yang diperlukan untuk mendapatakan suatu jasa. Penilaian dari kewajaran haraga kemungkinan besar didasarkan pada perbandingan transaksi yang melibatkan berbagai pihak. Penelitian ini merupakan replikasi dari penelitian sebelumnya yang dilakukan oleh (Simanjuntak \& Soesanto, 2018) variabel harga, kualitas layanan, dan brand image dalam variabel independen, karena harga yang dibayarkan oleh konsumen sesuai dengan layanan yang didapatkan dan hal ini membuat citra perusahaan menjadi baik dimata konsumen, hal ini mampu membuat konsumen untuk membuat keputusan pembelian ulang. Namun peneliti hanya menggunakan variabel harga, citra perusahaan terhadap keputusan pembelian ulang. Peneliti ini memiliki perbedaan dari peneliti sebelumnya yaitu dalam hal objek peneliti dan subjek peneliti. Dalam penelitian ini objek yang dipilih adalah maskapai penerbangan Citilink Indonesia, dan subjek yang dipilih adalah penumpang maskapai Citilink Indonesia di Bandar Udara Internasional Halim Perdanakusuma.

Berdasarkan fenomena dan uraian tersebut di atas, maka dilakukan penelitian dengan judul "Pengaruh Kewajaran Harga dan Citra Perusahaan Terhadap Keputusan Pembelian Ulang Pada Penumpang Maskapai Citilink Indonesia". Berdasarkan uraian latar belakang penelitian yang telah dikemukakan tersebut, maka masalah yang diidentifikasi oleh penulis adalah: Apakah kewajaran harga dan citra perusahaan secara parsial berpengaruh terhadap keputusan pembelian ulang pada penumpang maskapai Citilink Indonesia, Apakah kewajaran harga dan citra perusahaan secara simultan berpengaruh terhadap keputusan pembelian ulang pada penumpang maskapai Citilink Indonesia. Tujuan dari penelitian ini adalah untuk: mengetahui kewajaran harga dan citra perusahaan secara parsial berpengaruh terhadap keputusan pembelian ulang pada penumpang maskapai Citilink Indonesia, mengetahui kewajaran harga dan citra perusahaan secara simultan berpengaruh terhadap keputusan pembelian ulang pada penumpang maskapai Citilink Indonesia. Manfaat yang diharapkan dalam penelitian ini adalah: kegunaan teoritis, untuk menambah wawasan dan pengetahuan serta memperkaya khasanah penelitian, kegunaan praktis, untuk memberikan 
Jurnal Manajemen Bisnis, Vol 10. No.1, Maret 2019, E-ISSN:2622-6308 P-ISSN:2086-8200

Website: http://journal.umy.ac.id/index.php/mb

DOI:10.18196/mb.10168

kontribusi pemikiran bagi pihak perusahaan untuk merumuskan kebijakan pemasaran, sebagai bahan referensi peneliti lain yang bermaksud mengadakan penelitian yang sama mengenai kewajaran harga, citra perusahaan dan keputusan pembelian ulang.

\section{TINJAUAN PUSTAKA DAN PENGEMBANGAN HIPOTESIS}

Harga merupakan salah satu dari bauran pemasaran yang menghasilkan pendapatan. Elemen lain yaitu menghasilkan biaya. Pengertian harga adalah sebagai nilai tukar barang atau jasa; dengan kata lain, harga menunjukan bahwa apapun produk tersebut dapat ditukarkan di pasar. Kewajaran (fairness) didefinisikan sebagai suatu penilaian untuk suatuhasil dan proses agar mencapai hasil yang masuk akal dan dapat diterima (Kotler \& Keller, 2013). Aspek kognitif definisi ini menunjukan bahwa penelitian kewajaran harga melibatkan perbandingan prosedur harga yang terkait dengan standard, referensi atau norma. Perusahaan biasanya tidak menetapkan suatu harga, tetapi mengembangkan stuktur penetapan harga yang merevleksikan variasi dalam permintaan dan biaya secara geografis, kebutuhan segmen pasar, waktu pembelian, tingkat pemesanan, frekuensi pengiriman, garansi, kontrak layanan dan faktor lainnya (Kotler \& Keller, 2013). Sejumlah uang yang dibebankan atau dikelurkan atas sebuah produk atau jasa. Penentuan harga tepat yang harus lebih dulu dilakukan oleh perusahaan jika ingin perusahaan berhasil dalam memasarkan barang atau jasa, dan sebaliknya ketika perusahaan tidak mampu memberikan penetapan harga yang tepat pada konsumen dampak yang akan dirasakan adalah konsumen akan enggan untuk melakukan pembelian produk ataupun jasa diperusahaan tersebut (Budiastari, 2018).

Kewajaran harga merupakan kecenderungan konsumen untuk menggunakan harga dalam memberi penilaian tentang kesesuaian manfaat produk/jasa. Penilaian terhadap harga pada suatu manfaat produk/jasa dikatakan mahal, murah atau sedang dari masing-masing individu tidaklah sama, karena tergantung dari persepsi individu yang dilatarbelakangi oleh lingkungan dan kondisi individu itu sendiri. Persepsi konsumen terhadap suatu harga dapat mempengaruhi keputusannya dalam membeli suatu produk atau jasa sehingga suatu perusahaan harus mampu memberikan persepsi yang baik terhadap produk atau jasa yang mereka jual. Harga merupakan satu-satunya unsur bauran pemasaran yang memberikan pendapatan bagi perusahaan (Soelasih, 2014). 
Jurnal Manajemen Bisnis, Vol 10. No.1, Maret 2019, E-ISSN:2622-6308 P-ISSN:2086-8200

Website: http://journal.umy.ac.id/index.php/mb

DOI:10.18196/mb.10168

Dimensi pengukuran harga ada 2, yaitu: Harga yang dipersepsikan, yaitu persepsi pelanggan terhadap harga yang diterima, apakah tinggi, rendah atau adil. Harga yang direferensikan, yaitu referensi dari pelanggan sebagai dasar perbandingan untuk menilai. penilaian dari kewajaran harga kemungkinan besar didasarkan pada perbandingan transaksi yang melibatkan berbagai pihak, kewajaran harga adalah suatu penilaian untuk suatu hasil dan proses yang dapat diterima oleh pelanggan (Widodo, Harini, \& Haryono, 2018). Beberapa atribut kewajaran harga adalah sebagai berikut: (1) Pelanggan merasa membayar dengan harga yang wajar pada setiap transaksi pembelian, (2) Referensi tingkat harga, ketika pelanggan merasa wajar apabila suatu produk atau jasa dengan jenis yang sama dari perusahaan yang berbeda namun dengan harga yang berbeda pula, (3) Kebijakan harga akan suatu produk atau jasa yang ditentukan oleh perusahaan adalah hal yang wajar dan dapat diterima oleh konsumen, (4) Harga yang ditetapkan oleh perusahaan merupakan sebuah etika, dimana pelanggan diberitahu mengenai perubahan harga yang akan dilakukan oleh perusahaan tersebut sebelum harga yang baru ditetapkan (Savitri, 2018).

Harga merupakan apa yang kita dapat dari suatu yang telah kita korbankan untuk memperoleh produk atau jasa (Suryonaningsih, Paramita, \& Hasiholan, 2016). Sedangkan menurut (Wirtz \& Kimes, 2007) harga dapat diartikan sebagai jumlah uang (satuan moneter) dan/ atau aspek lain (non-moneter) yang mengandung utilitas atau kegunaan tertentu yang diperlukan untuk mendapatkan suatu jasa. Produk dengan mutu jelek, harga yang mahal, penyerahan produk yang lambat dapat membuat pelanggan tidak puas, hal itu menunjukan bahwa harga merupakan salah satu penyebab ketidakpuasan para pelanggan. Harga adalah jumlah keseluruhan nilai yang diberikan konsumen untuk manfaat yangdidapatkan atau digunakan atas produk dan jasa. Dalam tujuan penetapan harga ada 4 hal yang mendasarinya, yaitu: Tujuan penetapan yang berorientasi pada laba, yang mendasarinya yaitu pada asumsi teori ekonomi klasik dimana bahwa sebuh perusahaaan selalu ingin mendapatkan harga yang maksimum, namun penerapannya sangat sulit dilakukan jika didalam persaingan terjadi kondisi yang ketat dan serba kompleks, Tujuan harga yaitu berorientasi pada volume, pada tahap ini tujuan penetapan harga dalah berorientasi pada volume dimana ketika perusahaan ingin mencapai target dan nilai penjualan bahkan untuk menguasai pasar maka harga akan ditetapkan sedemikian rupa, misalnya: biaya oprasional pemasangan jalur telepon untuk satu rumah tidak berbeda jauh dengan biaya pemasangan untuk lima rumah (Wirtz \& Kimes, 2007). Tujuan harga yaitu berorientasi pada citra. Ketika 
Jurnal Manajemen Bisnis, Vol 10. No.1, Maret 2019, E-ISSN:2622-6308 P-ISSN:2086-8200

Website: http://journal.umy.ac.id/index.php/mb

DOI:10.18196/mb.10168

perusahaan ingin membentuk dan mempertahankan citra perusahaan maka perusahaan akan menetapkan harga yang tinggi, namun sebaliknya, jika perusahaan ingin mempertahankan dan membentuk citra nilai tertentu maka perusahaan akan menetapkan harga rendah. Tujuan penetapan harga sebagai stabilisasi. Ketika perusahaan ingin mempertahankan hubungan yang stabil antara harga suatu perusahaan dengan harga pemimpin industri.

Beberapa buku pemasaran banyak menuliskan bagaimana pentingnya penetapan harga bagi suatu perusahaan. Salah satunya yaitu dari (Wirtz \& Kimes, 2007) tujuan penetapan harga bagi perusahaan yaitu sebagai berikut: Meningkatkan pertumbuhan penjualan (maximize sales growth), Mempertahankan kualitas atau diferensiasi layanan (maintain quality or service differentiation), Memaksimalkan keuntungan saat ini; metode skimming dan harvesting (maximize current profit; skimming and harvesting), Kemampuan bertahan (survival), Tujuan social (social objectives). Dalam mengevaluasi kepuasan harga, perusahaan sebaiknya sengenal lebih jauh harga yang dipersepsikan dalam benak pelanggan. Hal ini senada dengan (George, 2013) bahwa pemahaman harga merupakan prioritas pemasaran yang penting. Berikut ini tiga topik utama mengenai harga, yaitu: Harga referensi, Asumsi harga-kualitas, Akhiran harga. Banyak penjual yakni bahwa harga harus berakhiran ganjil. Misalnya Rp99.999. hal ini dilakukan untuk memainkan psikologi pelanggan, bahwa harga tersebut dipersepsikan oleh pelanggan sebagai potongan harga atau harga yang murah.

Citra perusahaan adalah persepsi seseorang mengenai suatu citra organisasi dan persepsi-persepsi ini diciptakan melalui seluruh indera: penglihatan, pendengaran, penciuman, peraba, citra rasa dan perasaan yang dialami melalui penggunaan produk, pelayanan konsumen, lingkungan komersial dan komunikasi perusahaan, itu merupakan hasul dari setiap perusahaan yang dilakukan atau tidak dilakukan (Kotler \& Keller, 2013). Citra perusahaan tidak dapat dibuat hanya dalam semalam, sebaiknya citra perusahaan harus dibangun oleh perusahaa tersebut guna memberikan kesan dan persepsi positif bagi konsumen. Citra merupakan seperangkat keyakinan, ide, dan kesan yang dimiliki oleh seseorang terhadap suatu objek (Kotler \& Keller, 2013).

Membentuk citra hubungan baik dengan para pelanggan ada perbedaan prinsip antara jasa dengan barang yaitu: Barang berwujud-Jasa tak berwujud. Jasa tidak dapat disimpan atau digunakan, tidak bisa dipatenkan, dipanjangkan dan diperlihatkan, Barang ada standard, jasa bersifat heterogen. Kepuasan terhadap jasa, sangat tergantung pada orang yang melayani, kualitas banyak dipengaruhi oleh faktor-faktor uncontrollable, taka da jaminan 
Jurnal Manajemen Bisnis, Vol 10. No.1, Maret 2019, E-ISSN:2622-6308 P-ISSN:2086-8200

Website: http://journal.umy.ac.id/index.php/mb

DOI:10.18196/mb.10168

jasa yang diberikan persis cocok dengan jasa yang direncanakan sebelumnya, Produksi barang terpisah dengan waktu konsumsi. Konsumsi ikut berpartisipasi dalam transaksi, jasa sulit diproduksi massal. Barang bersifat Non Perishable, jasa bersifat Perishable adalah sifat sulit mensinkronkan antara penerapan dan permintaan jasa tak bias dijual kemudian dan jasa tak bias di retur (Alma, 2002). Macam jenis citra (image) meliputi 3 macam yaitu: Mirror image yaitu Suatu perusahaan atau organisasi harus mampu melihat sendiri bagaimana image yang mereka tampilkan dalam melayanimpubliknya. Lembaga harus dapat mengevaluasi penampilan mereka apakah sudah maksimal dalam memberi layanan atau masih dapat ditingkatkan lagi, ini disebut mirror image. Multiple image yaitu adakalanya anggota masyarakat memiliki image terhadap perusahaan, misalnya ada yang sudah merasa puas, bagus, dan ada yang merasa masih banyak kekurangan dan perlu diperbaiki. Ada yang merasa puas untuk sebagian layanan, dan tidak merasa puas dengan sektor layanan lain, ini dinamakan multiple image. Current image yaitu Bagaimana citra terhadap perusahaan pada umumnya dinamakan Current image. Current image ini perlu diketahui oleh seluruh karyawan perusahaan, sehingga dimana ada kemungkinan image umum ini dapat diperbaiki (Alma, 2002).

Eleman-elemen citra perusahaan menurut (Kotler \& Keller, 2013): Kepribadian yaitu keseluruhan karakteristik yang dipahami publik sasaran seperti perusahaan yang dapat dipercaya, perusahaan yang mempunyai tanggung jawab. Reputasi yaitu Hak yang telah dilakukan perusahaan dan diyakini publik sasaran berdasarkan pengalaman sendiri maupun pihak lain seperti kineja keamanaan transaksi sebuah bank. Nilai yaitu Nilai-nilai yang dimiliki suatu perusahaan dengan kata lain budaya perusahaan seperti sikap manajemen yang peduli terhadap pelanggan, karyawan yang cepat tanggap terhadap permintaan maupun keluhan pelanggan. Identitas Perusahaan yaitu Komponen-komponen yang memper mudah pengenalan publik sasaran terhadap perusahaan seperti logo, warna dan slogan.

Membangun sebuah citra tidak mudah karena adanya persepsi yang relative konsisten dalam jangka waktu panjang. Akan susah mengubah citra ketika telah sekali saja terbentuk. Suatu citra harus terbentuk secara jelas dan mempunyai keunggulan apabiladisandingkan atau dibandingkan dengan perusahaan pesaing, saat ada perbedaan dan keunggulan merek yang dihadapkan dengan merek lain (Widodo, Harini, \& Haryono, 2018). 
Jurnal Manajemen Bisnis, Vol 10. No.1, Maret 2019, E-ISSN:2622-6308 P-ISSN:2086-8200

Website: http://journal.umy.ac.id/index.php/mb

DOI:10.18196/mb.10168

Citra perusahaan berupa pengetahuan dan kepercayaan konsumen pada suatu atribut merek (aspek kognitif) penggunaan merek yang memiliki konsekuensi, dan situasi penggunaan yang sesuai, begitu juga dengan evaluasi, perasaan dan emosi yang diasosiasikan dengan merek tersebut (aspek efektif), konsumen yang memiliki persepsi dan preferensi terhadap merek, sebagaimana asosiasi merek yang mampu merefleksikan merek dalam ingatan konsumen merupakan definisi dari citra perusahaan. Meskipun asosiasi merek dapat terjadi dalam berbagai macam bentuk tapi dapat dibedakan menjadi asosiasi performansi dan asosiasi imajinari yang berhubungan dengan atribut dan kelebihan merek (Savitri, 2018).

Suatu perilaku yang dilakuan konsumen setelah melakukan pembelian yang sebelumnya telah didasari dengan kepuasan yang akan ditunjukan dengan prilaku konsumen itu untuk melakukan pembelian lagi pada produk atau jasa yang sama dalam kesempatan selanjutnya merupakan pembelian ulang (Kotler \& Keller, 2013). Mengemukakan bahwa konsumen memiliki dua tipe pembelian yaitu pembelian percobaan dan pembelian ulang. Ketika konsumen membeli suatu produk dengan merk tertentu untuk pertama kalinya dan konsumen dalam tindakan tersebut berusaha menyelidiki dan mengevaluasi produk atau jasa dengan langsung mencoba hal ini disebut pembelian percobaan. Dan pembelian ulang terjadi ketika konsumen merasakan puas dengan produk atau jasa tertentu dan melakukan pembelian produk atau jasa tersebut untuk kedua kali dan seterusnya. Dari beberapa definisi mengenai keputusan pembelian ulang diatas maka dapat disimpulkan bahwa keputusan pembelian ulang merupakan kegiatan pembelian yang dilakukan konsumen stelah mereka melakukan pembelian yang pertama kali dari produk maupun jasa yang dilakukan secara berulang pada jangka waktu tertentu dan secara aktif menyukai dan mempunyai sikap positif terhadap suatu produk barang atau jasa, didasarkan pada pengalaman yang telah dilakukan dimasa lampau.

Faktor utama yang mempengaruhi minat seseorang untuk melakukan pembelian ulang, yaitu: Faktor Psikologis yaitu Meliputi pengalaman belajar individu tentang kejadian di masa lalu, serta pengaruh sikap dapat didefinisikan sebagai suatu perubahan perilaku akibat pengalaman sebelumnya. Timbulnya minat konsumen untuk melakukan pembelian ulang sangat dipengaruhi oleh pengalaman belajar individu dan pengalaman belajar konsumen yang akan menentukan tindakan dan pembelian keputusan membeli (Kotler \& Keller, 2013). 
Jurnal Manajemen Bisnis, Vol 10. No.1, Maret 2019, E-ISSN:2622-6308 P-ISSN:2086-8200

Website: http://journal.umy.ac.id/index.php/mb

DOI:10.18196/mb.10168

Proses pengambilan keputusan adalah proses dimana seseorang konsumen akan melalui tahap mulai dari pengenalan kebutuhan, pencarian informasi, evaluasi alternatif, keputusan pembelian hingga perilaku pasca beli. Proses pembelian ulang konsumen terjadi ketika konsumen merasa puas pada pembelian percobaan produk atau jasa dan konsumen memiliki keinginan yang tinggi untuk melakukan pembelian kembali produk atau jasa yang sama dan juga kemungkinan untuk mengajak orang lain pun tinggi. Proses pengambilan keputusan pembelian sangat bervariasi, adapun proses ini digambarkan secara sederhana ada pula yang menggambarkan proses ini secara luas dan kompleks. Perilaku konsumen yang sebelumnya telah didasari oleh kepuasaan setelah melakukan pembelian merupakan pembelian ulang, ketika konsumen merasa puas pada produk atau jasa yang telah dibeli maka konsumen akan memperlihatkan peluang untuk membeli kembali yang lebih tinggi pada kesempatan berikutnya (Kotler \& Keller, 2013).

\section{HASIL PENELITIAN TERDAHULU}

Kewajaran harga dan citra perusahaan memberikan pengaruh terhadap keputusan pembelian ulang konsumen, pada umumnya konsumen akan akan melakukan pembelian ulang ketika mereka telah memiliki persepsi bahwa produk atau jasa pada perusahaan tersebut memiliki harga yang sesuai dengan kualitas yang diterima pada saat pembelian sbelumnya, citra perusahaan juga berpengaruh terhadap keputusan pembelian ulang dimana konsumen akan merasa percaya untuk melakukan pembelian ulang ketika produk atau jasa yang diterima berasal dari perusahaan atau mempunyai merek yang memiliki persepsi kuat dibenak konsumen. Hal ini sejalan dengan penelitian yang dilakukan oleh Puspitasari dengan hasil penelitian yaitu Persepsi Kualitas dan Kepuasan Pelanggan Berpengaruh Terhadap Minat Beli Ulang. Perusahaan biasanya tidak menetapkan satu harga, tetapi mengembangkan struktur penetapan harga yang merefleksikan variasi dalam permintaan dan biaya secara geografis, kebutuhan segmen pasar, waktu pembelian, tingkat pemesanan, frekuensi pengiriman, garansi, kontrak layanan, dan faktor lainnya (Puspitasari, 2006). Penetapan harga menjadi hal yang paling penting untuk diperhatikan oleh perusahaan, dimana pelanggan akan lebih tertarik untuk melakukan pembelian ulang terhadap suatu produk ataupun jasa jika harga yang ditetapkan oleh perusahaan tersebut sesuai dengan kualitas dari perusahaan tersebut (Kotler \& Keller, 2013). Harga berhubungan dengan kemampuan dan kemauan pelanggan untuk membeli produk atau jasa, harga juga merupakan ukuran pelanggan yang 
Jurnal Manajemen Bisnis, Vol 10. No.1, Maret 2019, E-ISSN:2622-6308 P-ISSN:2086-8200

Website: http://journal.umy.ac.id/index.php/mb

DOI:10.18196/mb.10168

berhubungan dengan kualitas yang dimiliki produk atau jasa. Hal ini sejalan dengan penelitian yang dilakukan oleh Akbar dengan hasil penelitian bahwa kewajaran harga, citra perusahaan berpengaruh positif signifikan terhadap kepuasan dan loyalitas pelanggan. Citra perusahaan sebagai seperangkat keyakinan, ide dan kesan yang dimiliki oleh seseorang terhadap suatu merek, karena itu sikap dan tindakan pelanggan terhadap suatu merek sangat ditentukan oleh citra perusahaan tersebut (Akbar \& Parvez, 2009). Citra perusahaan merupakan syarat dari merek yang kuat. Citra perusahaan menjadi hal yang sangat penting dalam penjualan produk atau jasa karena citra perusahaan akan memberikan sebuah ingatan kepada pelanggan tentang produk atau jasa yang memiliki nilai positif dimata konsumen, hal ini juga menjadi acuan bagi pelanggan untuk lebih mudah ketika mencari produk atau jasa yang pernah dia beli sebelumnya (Kotler \& Keller, 2013). Citra terhadap perusahaan memiliki hubungan antara sikap pelanggan terhadap perusahaan. Hasil ini sesuai dengan penelitian Martenson dengan hasil citra merek, persepsi harga, dan kualitas produk secara simultan berpengaruh signifikan terhadap keputusan pembelian, Citra merek berpengaruh positif dan signifikan terhadap keputusan pemelian, persepsi harga berpengaruh negative dan signifikan terhadap keputusan pembelian, kualitas produk berpengaruh positif dan signifikan terhadap keputusan pembelian (Martenson, 2007).

\section{HIPOTESIS}

Untuk menguji permasalahan penelitian, peneliti akan menguji model penelitian yang mengekplorasi pengaruh antara kewajaran harga dan citra perusahaan terhadap keputusan pembelian ulang. Hipotesis tersebut dapat dideskripsikan sebagai berikut:

$\mathrm{H1}=$ Kewajaran harga dan citra perusahaan berpengaruh terhadap keputusan pembelian ulang pelanggan maskapai Citilink Indonesia secara parsial.

$\mathrm{H} 2=$ Kewajaran harga dan citra perusahaan berpengaruh terhadap keputusan pembelian ulang pelanggan maskapai Citilink Indonesia secara simultan.

\section{MODEL PENELITIAN}

Berikut adalah model penelitian yang menunjukkan hubungan antara Kewajaran harga dan citra perusahaan berpengaruh terhadap keputusan pembelian ulang pelanggan maskapai Citilink Indonesia secara parsial maupun simultan. Model hubungan tersebut dapat dijelaskan pada gambar dibawah: 
Jurnal Manajemen Bisnis, Vol 10. No.1, Maret 2019, E-ISSN:2622-6308 P-ISSN:2086-8200

Website: http://journal.umy.ac.id/index.php/mb

DOI:10.18196/mb.10168

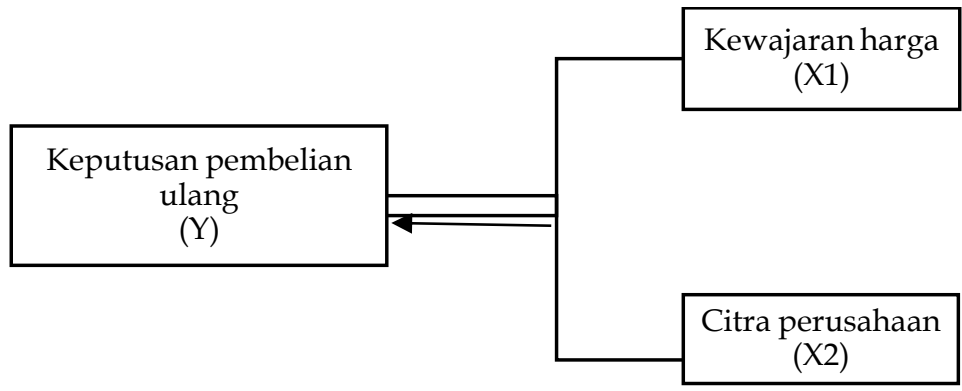

Gambar 1. Model penelitian

\section{METODE PENELITIAN}

Lokasi dalam penelitian ini adalah di Bandar Udara Internasional Halim Perdanakusuma, lokasi tersebut dipilih karena memiliki semua aspek pendukung sehingga penelitian dapat berjalan dengan baik.

Penelitian ini menggunakan nonprobability sampling yang dipilih adalah "purposive sampling" yaitu teknik penentuan sampel dengan pertimbangan/ kriteria tertentu (Tjahjono, 2015). Kriteria yang digunakan adalah masyarakat yang pernah menggunakan jasa penerbangan Citilink Indonesia lebih dari 2x. Sampling yang dipilih adalah responden yang dekat dengan lokasi penelitian karena mengingat adanya keterbatasan waktu, tenaga, dan biaya dalam memerlukan penelitian. Dalam Ferdinand (2002), ukuran sampel tergantung pada jumlah indikator dikalikan 5 sampai dengan 10. Dalam penelitian ini digunakan ukuran sampel yaitu dengan mengalikan jumlah seluruh indikator (11 indikator x $5=55$ ). Sehingga dalam penelitian ini menyebarkan 55 kuesioner kepada pengguna maskapai Citilink Indonesia di Bandara Halim Perdanakusuma.

Data yang digunakan dalam penelitian ini adalah data primer. Sumber data diperoleh dari hasil kuesioner yang telah dibagikan kepada 55 calon penumpang Citilink Indonesia yang berada di dalam ruang tunggu Bandar Udara Halim Perdanakusuma, kemudian data diolah menggunakan SPSS for windows for evaluation 15.0.

Uji Analisis dalam penelitian ini menggunakan regresi linier berganda. Analisis ini untuk memprediksi nilai dari variabel dependen apabila nilai variabel independen mengalami kenaikan atau penurunan dan untuk mengetahui arah hubungan, antara variabel independen dengan variabel dependen apakah masing-masing variabel independen berhubungan positif atau negative.

Perhitungan regresi linier berganda dihitung sebagai berikut: 
Jurnal Manajemen Bisnis, Vol 10. No.1, Maret 2019, E-ISSN:2622-6308 P-ISSN:2086-8200

Website: http://journal.umy.ac.id/index.php/mb

DOI:10.18196/mb.10168

$$
\mathrm{Y}=\mathrm{a}+\mathrm{b}_{1} \mathrm{X}_{1}+\mathrm{b}_{1} \mathrm{X}_{2}+\mathrm{e}
$$

Keterangan:

Y

a

: Keputusan Pembelian Ulang

$b_{1} s / d b_{2} \quad$ : Parameter Koefisien Regresi

$\mathrm{X}_{1} \quad$ : Kewajaran Harga

$\mathrm{X}_{2} \quad$ : Citra Perusahaan

e : Unsur Ganggu

Uji statistik F pada dasarnya menunjukan apakah semua variabel independen yang dimasukkan dalam model mempunyai pengaruh secara bersama-sama terhadap variabel terkait (Sugiyono, 2012). Untuk menguji pengaruh kedua hipotesis ini digunakan uji statistik F: (1) Quick look : bila nilai F lebih besar dari pada 4 maka Ho dapat ditolak pada derajat kepercayaan 5\% dengan kata lain kita menerima hipotesis alternative, yang menyatakan bahwa semua variabel independen secara serentak dan signifikan mempengaruhi variabel dependen.

Membandingkan nilai $\mathrm{F}$ hasil perhitungan dengan nilai $\mathrm{F}$ menurut tabel. Bila nilai $\mathrm{F}$ hitung lebih besar dari pada nilai $\mathrm{F}$ tabel maka Ho ditolak dan Ha diterima.

Uji statistic t pada dasarnya menunjukan seberapa jauh pengaruh satu variabel independen secara individual dalam menrangkan variabel dependen. Pengujian dilakukan dengan menggunakan signifikan level 0,05 ( $\mathrm{a}=5 \%)$. Penerimaan atau penolakan hipotesis dilakukan dengan kriteria: Jika nilai signifikan > 0,05 maka hipotesis ditolak (koefisien regresi tidak signifikan). Ini berarti secara persial variabel independen tidak mempunyai pengaruh secara signifikan terhadap variabel dependen. Jika nilai signifikan $\leq 0,05$ maka hipotesis diterima (koefisien regresi signifikan). Ini terjadi secara parsial variabel independen tersebut mempunyai pengaruh yang signifikan terhadap variabel dependen (Sugiyono, 2012).

\section{HASIL DAN PEMBAHASAN}

Penelitian ini bertujuan untuk mengetahui pengaruh kewajaran harga dan citra perusahaan terhadap keputusan pembelian ulang maskapai Citilink Indonesia Bandara Internasional Halim Perdanakusuma. Pengambilan sampel dilakukan dengan menggunakan metode nonprobability sampling. Peneliti menyebarkan 55 kuesioner kepada calon penumpang 
Jurnal Manajemen Bisnis, Vol 10. No.1, Maret 2019, E-ISSN:2622-6308 P-ISSN:2086-8200

Website: http://journal.umy.ac.id/index.php/mb

DOI:10.18196/mb.10168

maskapai Citilink Indonesia. Dari 55 kuesioner yang disebarkan, semua terisi dan dapat dioleh sehingga response rate penelitian ini adalah 100,00\%. Gambaran tentang responden yang menjadi sampel dalam penelitian ini di klasifikasikan berdasarkan usia, jenis kelamin dan pekerjaan penumpang. Berikut ini akan dibahas mengenai kondisi dari masing-masing klasifikasi demografis responden tersebut.

Tabel 1. Pengelompokan Responden Berdasarkan Usia:

\begin{tabular}{lcl}
\hline Usia & Jumlah Responden & Persentase \\
\hline$<21$ tahun & 9 & $16,4 \%$ \\
\hline $\mathbf{2 1 - 2 5}$ tahun & 12 & $21,8 \%$ \\
\hline $\mathbf{2 6 - 3 0}$ tahun & 11 & $20 \%$ \\
\hline 31-35 tahun & 15 & $27,3 \%$ \\
\hline $\mathbf{3 5}$ tahun & 8 & $14,5 \%$ \\
\hline Total & 55 & $100 \%$
\end{tabular}

Berdasarkan tabel diatas, hasil kuesiner yang disebarkan pada 55 responden yaitu calon penumpang masakapi Citilink Indonesia di Bandara Internasional Halim Perdanakusuma, diketahui sebagian besar responden berusia 31-35 tahun sebanyak 15 responden $(27,3 \%)$, responden berusia 21-25 tahun sebanyak 12 responden $(21,8 \%)$, responden berusia 26-30 tahun sebanyak 11 responden $(20 \%)$, responden berusia $<21$ tahun sebanyak 9 responden $(16,4)$, responden berusia $>35$ tahun sebanyak 8 responden $(14,5 \%)$.

Tabel 2. Pengelompokan Responden Berdasarkan Jenis Kelamin:

\begin{tabular}{lcl}
\hline Jenis Kelamin & Jumlah Responden & Presentase \\
\hline Pria & 20 & $36,4 \%$ \\
\hline Wanita & 35 & $63,6 \%$ \\
\hline Total & 55 & $100 \%$
\end{tabular}

Berdasarkan tabel diatas, hasil kuesioner yang disebarkan pada 55 responden yaitu calon penumpang masakapi Citilink Indonesia di Bandara Internasional Halim Perdanakusuma, diketahui sebagian besar responden berjenis kelamin pria sebanyak 20 responden $(36,4 \%)$ dan yang berjenis kelamin wanita sebanyak 35 responden $(63,6 \%)$.

Tabel 3. Pengelompokan Responden Berdasarkan Pendidikan: 
Jurnal Manajemen Bisnis, Vol 10. No.1, Maret 2019, E-ISSN:2622-6308 P-ISSN:2086-8200

Website: http://journal.umy.ac.id/index.php/mb

DOI:10.18196/mb.10168

\begin{tabular}{ccc}
\hline Pendidikan & Jumlah Responden & Presentase \\
\hline S2 & 10 & $18,2 \%$ \\
\hline S1 & 19 & $34,5 \%$ \\
\hline DIV & 3 & $5,5 \%$ \\
\hline DIII & 8 & $14,5 \%$ \\
\hline SLTA/Sederajat & 15 & $27,3 \%$ \\
\hline Total & 55 & $100 \%$
\end{tabular}

Berdasarkan tabel diatas, hasil kuesioner yang disebarkan pada 55 responden yaitu calon penumpang masakapi Citilink Indonesia di Bandara Internasional Halim Perdanakusuma, diketahui sebagian besar responden dengan pendidikan S2 sebanyak 10 responden $(18,2 \%)$, responden dengan pendidikan S2 sebanyak 19 responden $(34,5 \%)$, responden dengan pendidikan DIV sebanyak 3 responden $(5,5 \%)$, responden dengan pendidikan DIII sebanyak 8 responden $(14,5 \%)$, dan responden dengan pendidikan SLTA/Sederajat sebanyak 15 responden $(27,3 \%)$.

Penelitian ini menggunakan Product Moment dengan taraf signifikan sebesar a $=5 \%$. Jika $r_{\text {hitung }} \geq r_{\text {tabel }}$, maka pernyataan yang didapatkan dalam kuesiner dinyatakan valid. Pada penelitian ini responden berjumlah 55 calon penumpang Citilink Indonesia, sehingga dapat dihitung $r_{\text {tabel }}$ sebagai berikut:

$R_{\text {tabel }}=a ; n-2=0,05 ; 55-2=0,266$

Berdasarkan hasil perhitungan uji validitas menggunkaan variabel kewajaran harga dengan 4 pertanyaan adalah sebagai berikut:

Tabel 4. Hasil Uji Variabel Kewajaran Harga $\left(X_{1}\right)$

\begin{tabular}{cccc}
\hline $\begin{array}{c}\text { Butir } \\
\text { Pernyataan }\end{array}$ & $\begin{array}{c}\text { Nilai Corrected } \\
\text { Item Total Correlation/ } \\
\boldsymbol{r}_{\text {hitung }}\end{array}$ & $\mathbf{r}_{\text {tabel }}$ & Kriteria \\
\hline P1 & 0,805 & 0,266 & Valid \\
\hline P2 & 0,882 & 0,266 & Valid \\
\hline P3 & 0,905 & 0,266 & Valid \\
\hline P4 & 0,867 & 0,266 & Valid \\
\hline
\end{tabular}


Jurnal Manajemen Bisnis, Vol 10. No.1, Maret 2019, E-ISSN:2622-6308 P-ISSN:2086-8200

Website: http://journal.umy.ac.id/index.php/mb

DOI:10.18196/mb.10168

Berdasarkan tabel diatas maka dapat dilihat bahwa seluruh pertanyaan untuk variabel Kewajaran Harga memiliki status valid, karena nilai $r_{\text {hitung }}$ (Corrected Item-Total Correlation) $>$ $r_{\text {tabel }}$ sebesar 0,266 .

Tabel 5. Hasil Uji Variabel Citra Perusahaan $\left(X_{2}\right)$

\begin{tabular}{cccc}
$\begin{array}{c}\text { Butir } \\
\text { Pernyataan }\end{array}$ & $\begin{array}{c}\text { Nilai Corrected Item } \\
\text { Total Correlation/ } \text { hitung }_{\text {htal }}\end{array}$ & $\mathbf{r}_{\text {tabel }}$ & Kriteria \\
\hline P1 & 0,880 & 0,266 & Valid \\
\hline P2 & 0,942 & 0,266 & Valid \\
\hline P3 & 0,903 & 0,266 & Valid \\
\hline P4 & 0,818 & 0,266 & Valid \\
\hline
\end{tabular}

Berdasarkan tabel diatas maka dapat dilihat bahwa seluruh pertanyaan untuk variabel Citra Perusahaan memiliki status valid, karena nilai $r_{\text {hitung }}$ (Corrected Item-Total Correlation) $>$ $r_{\text {tabel }}$ sebesar 0,266.

Tabel 6. Hasil Uji Variabel Keputusan Pembelian Ulang (Y)

\begin{tabular}{cccc}
\hline $\begin{array}{c}\text { Butir } \\
\text { Pernyataan }\end{array}$ & $\begin{array}{r}\text { Nilai Corrected Item } \\
\text { Total Correlation/ } \boldsymbol{r}_{\text {hitung }}\end{array}$ & $\mathbf{r}_{\text {tabel }}$ & Kriteria \\
\hline P1 & 0,771 & 0,266 & Valid \\
\hline P2 & 0,901 & 0,266 & Valid \\
\hline P3 & 0,919 & 0,266 & Valid \\
\hline
\end{tabular}

Berdasarkan tabel diatas maka dapat dilihat bahwa seluruh pertanyaan untuk variabel Keputusan Pembelian Ulang memiliki status valid, karena nilai $r_{\text {hitung }}$ (Corrected Item-Total Correlation) $>r_{\text {tabel }}$ sebesar 0,266.

Dalam penelitian ini pengukuran uji reliabilitas menggunakan teknik Alpha Cronbach. Teknik ini digunakan untuk menentukan apakah suatu instrument penelitian reabel atau tidak, bila jawaban responden berbentuk skala, seperti 1-3, 1-5 atau 1-7 atau jawaban responden yang menginterprestasikan penilaian sikap. Kriteria suatu intrumen penelitian dikatakan reabel dengan menggunakan teknik ini, bila reliabilitas $\mathrm{r}_{-11}>0,6$ (Sugiyono, 2007).

Uji Reliabilitas dilakukan terhadap item pernyataan yang dinyatakan valid. Satu dikatakan reliable atau handal jika jawaban terhadappernyataan selalu konsisten. Koefisien reliabilitas instrument untuk melihat konsistensi jawaban butir-butir pernyataan 
Jurnal Manajemen Bisnis, Vol 10. No.1, Maret 2019, E-ISSN:2622-6308 P-ISSN:2086-8200

Website: http://journal.umy.ac.id/index.php/mb

DOI:10.18196/mb.10168

yangdiberikan oleh responden. Adapun alat analisisnya menggunakan teknik Alpha Cronbach, penghitungan dibantu dengan program SPSS 15.0. Adapun reliabilitas untuk masing-masing varibel hasilnya disajikan pada tabel berikut ini:

Tabel 7. Hasil Uji Reliabilitas

\begin{tabular}{clccc}
\hline No. & Variabel & $\boldsymbol{r}_{\text {alpha }}$ & $\boldsymbol{r}_{\text {kritis }}$ & Kriteria \\
\hline $\mathbf{1}$ & Kewajaran Harga $\left(\mathrm{X}_{1}\right)$ & 0,881 & 0,600 & Reliabel \\
\hline $\mathbf{2}$ & Citra Perusahaan $\left(\mathrm{X}_{2}\right)$ & 0,898 & 0,600 & Reliabel \\
\hline $\mathbf{3}$ & Keputusan Pembelian Ulang & 0,793 & 0,600 & Reliabel
\end{tabular}

$(\mathrm{Y})$

Berdasarkan tabel diatas uji reliabilitas dilakukan terhadap item pernyataan yang dinyatakan valid. Suatu variabel dikatakan reliable atau handal jika jawaban terhadap pernyataan selalu konsisten. Jadi hasil koefisien reliabilitas instrumen kewajaran harga $\mathbf{r}_{11}=$ 0,881, instrumen citra perusahaan $r_{11}=0,898$, instrumen keputusan pembelian ulang $r_{11}=$ 0,793, ternyata memiliki nilai Alpha Cronbach lebih besar dari 0,600 yang berarti ketiga instrument dinyatakan reliabel atau memenuhi persyaratan.

Hasil pengujian regresi $\mathrm{H}_{1}$ pada dibawah ini:

Tabel 8. Hasil Uji Regresi

\begin{tabular}{|c|c|c|c|c|c|c|c|c|c|}
\hline $\begin{array}{l}\text { Variabel } \\
\text { Dependen }\end{array}$ & $\begin{array}{l}\text { Variabel } \\
\text { Independen }\end{array}$ & eta & Sig & & & $\begin{array}{l}\text { Adjusted } \\
\text { R Square }\end{array}$ & $\begin{array}{l}\mathbf{R} \\
\text { Square }\end{array}$ & $\mathbf{F}$ & sig \\
\hline Keputusan & Kewajaran & & & 0.00 & & 0.353 & 0 & 15.741 & \\
\hline $\begin{array}{l}\text { Pembelian } \\
\text { ulang }\end{array}$ & Harga & .184 & 4 & & .016 & & 377 & & .000 \\
\hline & $\begin{array}{l}\text { Citra } \\
\text { Perusahaan }\end{array}$ & .282 & 0 & 0.00 & .094 & & & & \\
\hline
\end{tabular}

Dari persamaan regresi tersebut dapat diinterprestasikan sebagai berikut: Nilai konstanta regresi sebesar 4,865, menunjukan pada kewajaran harga dan citra perusahaan dengan kondisi konstan atau $\mathrm{X}=0$, maka keputusan pembelian ulang maskapai Citilink Indonesia di Bandar Udara Halim Perdanakusuma sebesar 4,865. X $X_{1}$ (Kewajaran Harga) koefisien regresinya sebesar 0,184, mempunyai pengaruh positif atau berbanding lurus terhadap Y (Keputusan Pembelian Ulang). Artinya apabila kewajaran harga semakin baik dengan asumsi variabel lain konstan, maka hal tersebut depat meningkatkan keputusan pembelian ulang maskapai Citilink Indonesia di Bandar Udara Halim Perdanakusuma sebesar 0,184. $\mathrm{X}_{2}$ (Citra Perusahaan) koefisien regresinya sebesar 0,282, mempunyai pengaruh positif atau berbanding lurus terhadap Y (Keputusan Pembelian Ulang). Artinya apabila citra 
Jurnal Manajemen Bisnis, Vol 10. No.1, Maret 2019, E-ISSN:2622-6308 P-ISSN:2086-8200

Website: http://journal.umy.ac.id/index.php/mb

DOI:10.18196/mb.10168

perusahaan semakin baik dengan asumsi variabel lain konstan, maka hal tersebut depat meningkatkan keputusan pembelian ulang maskapai Citilink Indonesia di Bandar Udara Halim Perdanakusuma sebesar 0,282.

Menurut sugiyono pedoman untuk memberikan interpretasi koefisien korelasi sebagai berikut :

$$
\begin{aligned}
& 0,00-0,199=\text { sangat rendah } \\
& 0,20-0,399=\text { rendah } \\
& 0,40-0,599=\text { sedang } \\
& 0,60-0,799=\text { kuat } \\
& 0,90-0,1000=\text { sangat kuat }
\end{aligned}
$$

Sumber : (Sugiyono, 2017)

\section{KESIMPULAN}

Hasil analisis regresi baik secara simultan maupun secara parsial antara variabel kewajaran harga dan citra perusahaan terhadap keputusan pembelian ulang maskapi Citilink Indonesia di Bandara Internasional Halim Perdanakusuma, sebagai berikut: (1) Terdapat pengaruh kewajaran harga terhadap keputusan pembelian ulang maskapi Citilink Indonesia di Bandara Internasional Halim Perdanakusuma dengan nilai signifikansi 0,004. (2) Terdapat pengaruh Citra Perusahaan terhadap keputusan pembelian ulang maskapi Citilink Indonesia di Bandara Internasional Halim Perdanakusuma dengan nilai signifikansi 0,000. (3) Terdapat pengaruh kewajaran harga dan citra perusahaan secara simultan terhadap keputusan pembelian ulang maskapi Citilink Indonesia di Bandara Internasional Halim Perdanakusuma dengan nnilai signifikansi 0,000.

\section{DAFTAR PUSTAKA}

Akbar, M. M., \& Parvez, N. (2009). Impact of service quality, trust, and customer satisfaction on customers loyality. ABAC Joural, https://pdfs.semanticscholar.org/470e/32ad101a10ea656882b991a10884d229dbc4.p df Diakses 3 Juli 2019.

Alma, B. (2002). Manajemen Pemasaran dan Pemasaran Jasa. Bandung: Alfabeta.

Budiastari, S. (2018). PENGARUH KUALITAS PRODUK, PERSEPSI HARGA, DAN CITRA MEREK TERHADAP KEPUASAN DAN LOYALITAS PELANGGAN BETON SIAP PAKAI HOLCIM DI JAKARTA. Jurnal Dinamika Manajemen dan Bisnis, Vol 1 No 1 http://journal.unj.ac.id/unj/index.php/jdmb/article/view/3926 Diakses tanggal 17 Juni 2019.

George, R. (2013). Prinsip - prinsip manajemen . Jakarta: Bumi Aksara. 
Jurnal Manajemen Bisnis, Vol 10. No.1, Maret 2019, E-ISSN:2622-6308 P-ISSN:2086-8200

Website: http://journal.umy.ac.id/index.php/mb

DOI:10.18196/mb.10168

Kotler, P., \& Keller, K. (2013). Manajemen Pemasaran. Jakarta: Erlangga.

Puspitasari, D. (2006). ANALISIS PENGARUH PERSEPSI KUALITAS DAN KEPUASAN PELANGGAN TERHADAP MINAT BELI ULANG (Studi Kasus pada Maskapai Penerbangan Garuda Keberangkatan Semarang). Diponegoro University Institutional Repository, http://eprints.undip.ac.id/9698/ Diakses tanggal 3 Juli 2019.

Savitri, I. A. (2018). PENGARUH CITRA MEREK, KUALITAS PRODUK DAN PERSEPSI HARGA TERHADAP KEPUASAN DAN NIAT BELI ULANG. E Jurnal Manajemen, Vol 7 No 10 https://ojs.unud.ac.id/index.php/Manajemen/article/view/40281 Diakses tanggal 3 Juli 2019.

Simanjuntak, E. S., \& Ardani, I. G. (2018). PERAN BRAND IMAGE MEMEDIASI PENGARUH PROMOSI DAN HARGA TERHADAP LOYALITAS KONSUMEN UBER TAKSI DI DENPASAR. E-Journal Manajemen Unud, Vol 7 No. 2 https:/ / media.neliti.com/media/publications/254429-none-66362f09.pdf Diakses tanggal 3 Juli 2019.

Soelasih, Y. (2014). PENGARUH KUALITAS PELAYANAN DAN KEWAJARAN TARIF TERHADAP NILAI KONSUMEN SERTA RETENSI PELANGGAN UNTUK PENERBANGAN DOMESTIK NIAGA FULL SERVICES DI INDONESIA. Journal $\begin{array}{lllll}\text { Business and } & \text { Economic, } & \text { Vol } & 18 & \text { No }\end{array}$ http://ojs.uajy.ac.id/index.php/kinerja/article/view/514 Diakses tanggal 3 Juli 2019.

Sugiyono. (2012). Metode Penelitian Bisnis. Bandung: Alfabeta.

Suryonaningsih, A., Paramita, P. D., \& Hasiholan, L. B. (2016). Effect of price and image brand on consumer satisfaction with buying decision as intervening (study at gamis clothes in toko Lana Semarang). Journal of Managemen, Vol. 2 No. 2 http://jurnal.unpand.ac.id/index.php/MS/article/view/579 diakses tanggal 3 Juli 2019.

Tjahjono, H.K. (2015). Metode Penelitian Bisnis. VSM MM UMY

Widodo, S., Harini, C., \& Haryono, A. T. (2018). PENGARUH HARGA, CITRA MEREK DAN KUALITAS PRODUK TERHADAP LOYALITAS PELANGGAN DENGAN KEPUASAN PELANGGAN SEBAGAI VARIABEL INTERVENING. Jurnal Unpad, http://jurnal.unpand.ac.id/index.php/MS/article/download/1140/1112.

Wirtz, J., \& Kimes, S. E. (2007). The Moderating Role of Familiarity in Fairness Perceptions of Revenue Management Pricing. Journal of Service Research, https://www.researchgate.net/publication/242284988_The_Moderating_Role_of_Fa miliarity_in_Fairness_Perceptions_of_Revenue_Management_Pricing Diakses tanggal 3 July 2019. 